\title{
TANGGUNG JAWAB PEMILIK KOPERASI PADA SAAT TERJADI KREDIT MACET DITINJAU DARI TEORI KEPASTIAN HUKUM
}

\author{
RESPONSIBILITIES OF COOPERATIVE OWNERS IN THE \\ EVENT OFBAD CREDITS IS REVIEWED FROM THE LEGAL \\ CERTAINTY THEORY
}

\author{
Teguh Tresna Puja Asmara \\ Universitas Padjadjaran \\ email : teguh13001@mail.unpad.ac.id \\ Tarsisius Murwadji \\ Universitas Padjadjaran \\ email : t.murwadji@unpad.ac.id \\ Bambang Daru Nugroho \\ Universitas Padjadjaran \\ email : badarnuu@yahoo.com
}

\begin{abstract}
Cooperatives are one of the most concrete forms of joint ventures based on a kinship principle. Today, cooperatives are experiencing several problems, one of which is associated with a limited cooperative capital in developing its business. In order to overcome these problems, cooperatives do the same cooperation with banking in the form of credit. The provision of credit loan from the trade in the implementation can be experienced bad credit, however the cooperative must be responsible and if the cooperative asset is insufficient, the cooperative owner can also be held accountable. This research is descriptive analytic using empiric-juridical approach. The results shows that the responsibilities of the cooperative owner in the event of bad credit can be from his personal property, if the cooperative asset is not enough to pay credit. However, there are obscurity about cooperative owner, cooperative member that considered as owner, referred to Law number 25 of 1992 about Cooperation,can not be held accountable as the owner. The terms of ownership are reviewed from the legal certainty theory divided into three forms: the owner's obligation or responsibility, the rights of the owner, and the proof of ownership.
\end{abstract}

Keywords: Bad Credit, Cooperative, Legal Certainty, Owner, Responsibility

\begin{abstract}
Abstrak
Koperasi merupakan salah satu bentuk yang paling konkrit dari usaha bersama berdasar asas kekeluargaan.Dewasa ini, koperasi mengalami beberapa permasalahan, salah satunya terkait modal koperasi yang terbatas dalam mengembangkan usahanya. Guna mengatasi masalah tersebut, koperasi melakukan kerja samasalah satunya dengan perbankan dalam bentuk kredit.Pemberian pinjaman kredit dari perbankantersebut dalam pelaksanaannya dapat mengalami kedit macet, sehingga koperasi harus bertanggungjawab dan apabila harta koperasi tidak mencukupi maka pemilik koperasi juga dapat dimintai pertanggungjawaban.Penelitian ini bersifat deskriptif analitis dengan menggunakan pendekatan yuridis empiris.Hasil penelitian
\end{abstract}


menunjukan bahwa tanggung jawab pemilik koperasi dalam hal terjadi kredit macet dapat sampai harta pribadinya, apabila harta koperasi sudah tidak mencukupi untuk membayar kredit. Namun terdapat ketidakjelasan siapa pemilik koperasi,anggota koperasi yang disebut sebagai pemilik dalam Undang-Undang Nomor 25 Tahun 1992 tentang Perkoperasian tidak dapat dimintai pertanggungjawaban sebagai pemilik. Syarat kepemilikan ditinjau dari teori kepastian hukum terbagi ke dalam tiga bentuk yaitukewajiban atau tanggung jawab pemilik, hak-hak pemilik, dan bukti kepemilikan.

\section{Kata kunci: Kepastian Hukum, Koperasi, Kredit Macet, Pemilik, Tanggung Jawab}

\section{PENDAHULUAN}

Indonesia merupakan negara yang menganut konsep negara kesejahteraan (welfare state). Konsep negara kesejahteraan tersebut, dapat dilihat dalam pembukaan UndangUndang Dasar Negara Republik Indonesia Tahun 1945 (UUD 1945) tepatnya pada alinea ke empat tentang tujuan dibentuknya Pemerintah Negara Republik Indonesia yaitu untuk "Melindungi segenap bangsa Indonesia dan seluruh tumpah darah Indonesia dan untuk memajukan kesejahteraan umum, mencerdaskan kehidupan bangsa, dan ikut melaksanakan ketertiban dunia yang berdasarkan kemerdekaan, perdamaian abadi dan keadilan sosial".

Tujuan Bangsa Indonesia dalam pembukaan UUD 1945 kemudian dijadikan spirit dasar dalam penyelenggaraan negara yang peran utamanya adalah menjamin kemakmuran pada semua warganya. Lebih lanjut tujuan memajukan kesejahteraan umum yang berdasarkan keadilan sosial diterjemahkan dalam batang tubuh UUD 1945 tepatnya dalam Pasal 23, Pasal 27 Ayat (2), Pasal 31, Pasal 33, dan Pasal 34.

Negara kesejahteraan secara singkat didefinisikan sebagai suatu negara dimana pemerintahan negara dianggap bertanggung jawab dalam menjamin standar kesejahteraan hidup minimum bagi setiap warga negaranya. ${ }^{1}$ Artinya Indonesia sebagai negara yang menganut konsep negara kesejahteraan dituntut untuk bertanggungjawab dalam pemenuhan kebutuhan dasar hidup, mengatasi kemiskinan dan jaminan pekerjaan bagi rakyatnya.

Konsep negara kesejahteraan merupakan konsep negara dalam perannya di bidang ekonomi yang berada di antara negara yang menganut konsep otokrasi dengan negara yang menganut konsep liberal.Dalam sistem ekonomi yang menggunakan konsep otokrasi, bidang ekonomi diatur dan dilaksanakan semuanya oleh negara sangat sedikit peran pelaku ekonomi lainnya, sedangkan dalam sistem ekonomi liberal pelaksanaan ekonomi di laksanakan sebebas-bebasnya dan peran negara sangatlah kecil.Negara kesejahteraan merupakan konsep ekonomi yang berada di antara dua konsep tersebut, dimana peran negara dan pelaku ekonomi lainnya proporsional.

Indonesia harus menghadirkan pranata-kebijakan ekonomi dan pranata-kebijakan sosial yang berorientasi kerakyatan, keadilan dan kesejahteraan, yang mana hal ini dikehendaki oleh para pendiri bangsa mengenai penjelmaan negara Republik Indonesia sebagai Negara Kesejahteraan. ${ }^{2}$ Sebagai pembuat kebijakan, peran Negara Indonesia dalam bidang ekonomi diatur dalam UUD 1945.

Indonesia sebagai negara yang menganut sistem negara kesejahteraan dapat mengimplementasikan trilogi dasar dari Ki Hajar Dewantara dalam bidang ekonomi

\footnotetext{
${ }^{1}$ Darmawan Triwibowo dan Sugeng Bahagijo, 2006, Mimpi Negara Kesejahteraan, LP3ES, Jakarta, hlm.xv.

2 Yudi Latif, 2011, Negara Paripurna: Historisitas, Rasionalitas, dan Aktualitas Pancasila, Gramedia Pustaka Utama, Jakarta, hlm. 492.
} 
yang dikenal dengan peribahasa "Ing Ngarso Sung Tulodo, Ing Madyo Mangun Karso, Tut Wuri Handayani". Ing ngarso sung tulodo artinya negara harus berada di depan memberi teladan atau contoh dalam menjalankan perekonomian nasional. Ing madyo mangun karso artinya negara harus berada di tengah membangun prakarsa dan bekerjasama dengan pelaku ekonomi lainnya.Tut wuri handayani artinya negara harus dapat berada di belakang guna memberikan dorongan agar dapat memajukan para pelaku ekonomi.

Peranan Negara Indonesia dalam perekonomian terbagi menjadi dua hal, yaitu sebagai regulator dan aktor atau pelaksana.Peran negara sebagai regulator yaitu membuat peraturan-peraturan dalam kegiatan ekonomi yang bertujuan guna mendorong kegiatan ekonomi agar lebih optimal dan dapat menciptakan kesejahteraan umum.Sedangkan, peran negara sebagai aktor atau pelaksana dapat dilaksanakan melalui dibentuknya Badan Usaha Milik Negara (BUMN).

Peran negara sebagai aktor atau pelaksana dalam perekonomian nasional yang dalam hal ini BUMN tidak dapat lepas dari aktor ekonomi lainnya, yaitu salah satunya swasta dan koperasi.Selain itu, dalam pelaksanaan sistem ekonomi di Indonesia haruslah disusun sebagai usaha bersama berdasarkan asas kekeluargaan.Asas kekeluargaan dapat dipandang sebagai asas bersama yang bermakna persaudaraan, humanisme dan pemerataan sesuai asas-asas kemanusiaan. ${ }^{3}$

Wujud asas kekeluargaan dalam aktor atau pelaksana ekonomi salah satunya adalah koperasi. Koperasi berdasarkan Undang-Undang Nomor 25 Tahun 1992 tentang Perkoperasian (UU Perkoperasian) merupakan badan usaha yang beranggotakan orang seorang atau badan hukum koperasi dengan melandaskan kegiatannya berdasarkan prinsip koperasi sekaligus sebagai gerakan ekonomi rakyat yang berdasarkan atas asas kekeluargaan. Sebagai pelaku ekonomi, koperasi memiliki peran yang sangat penting untuk mewujudkan demokrasi ekonomi yang terkandung dalam Pasal 33 UUD $1945 .{ }^{4}$

Koperasi merupakan salah satu bentuk yang paling konkrit dari usaha bersama berdasar asas kekeluargaan sesuai dengan UUD $1945 .{ }^{5}$ Namun dewasa ini koperasi mengalami beberapa permasalahan, salah satunya yaitu terkait terbatasnya modal koperasi dan ketidakjelasan tanggung jawab pemilik koperasi dalam hal terjadi masalah. Terdapat ketidakjelasan hak-hak pemilik koperasi, bagaimana bukti dari kepemilikannya dan sejauh mana tanggung jawab pemilik koperasi tersebut saat terjadi masalah dalam hal ini salah satunya yaitu masalah kredit macet.

Tanggung jawab badan usaha dalam hal melaksanakan usahanya terbagi ke dalam dua bentuk yaitu pertanggungjawaban badan usaha tidak berbadan hukum dan badan usaha berbadan hukum. Badan usaha yang tidak berbadan hukum berdasarkan perjanjian, sedangkan badan usaha berbadan hukum karakteristiknya yaitu terdapat pemisahan kekayaan pemilik dengan kekayaan badan usaha. ${ }^{6}$ Pemilik mendelegasikan kewenangannya kepada pengurus sebagai organ yang bertanggungjawab menjalankan badan usaha. Pemisahan harta kekayaan pemilik yang dimasukkan ke dalam badan usaha berubah menjadi hak dan tanggung jawab.

\footnotetext{
${ }^{3}$ Rustam Effendi, Boy Syamsul Bakhri, dan Zul Ihsan Mu'arrif, "Konsep Koperasi Bung Hatta Dalam Perspektif Ekonomi Syariah", Jurnal Al-Hikmah, Vol. 15, No. 1, 2018, hlm. 113.

${ }^{4}$ Dian Cahyaningrum, "Bentuk Badan Hukum Koperasi Untuk Menjalankan Kegiatan Usaha Perbankan", Jurnal Negara Hukum, Vol. 8, No. 1, 2017, hlm. 10.

${ }_{5}$ Tarsisius Murwadji dan Achmad Hagi Robby, "Edukasi dan Penyehatan Koperasi Melalui Linkage Program Perbankan", Padjadjaran Jurnal Imu Hukum, Vol. 4, No. 3, 2017, hlm. 456.

${ }^{6}$ Abdulkadir Muhammad, 2010, Hukum Perusahaan Indonesia, Cetakan Ke Empat Revisi, PT Citra Aditya Bakti,Bandung, hlm. 84 .
} 
Pertanggungjawaban terhadap terjadinya kredit macet atau hutang piutang yang tidak dapat dibayar harus jelas oleh siapa dan sejauh mana tanggung jawabnya.Salah satu yang bertanggung jawab dalam hal kredit atau hutang piutang yang tidak dapat dibayar,selain oleh badan usaha jugaoleh pemilik badan usaha tersebut. Dalam koperasi terdapat ketidakjelasan siapa pemilik dari koperasi, bukti apa yang dimilikinya, apa saja haknya, dan sejauh mana tanggung jawabnya.

Koperasi sebagai badan usaha berbadan hukum dapat mengadakan hubungan bisnis dengan pihak lain dan memiliki kekayaan sendiri, yang terpisah dari kekayaan pengurus atau pemiliknya. Tanggung jawab koperasi apabila tidak dapat melaksanakan kewajibannya dalam hal kredit macet maka dikembalikan kepada koperasi itu sendiri sebagai sebuah badan usaha berbadan hukum dan apabila harta kekayaan koperasi tersebut tidak mencukupi maka pemilik dapat dimintai pertanggungjawaban sampai dengan harta pribadinya.

Pertanggungjawaban koperasi dalam menjalankan usahanya terbagi ke dalam dua ruang lingkup, yaitu internal dan eksternal.Tanggung jawab koperasi dalam ruang lingkup internal yaitu oleh pengurus dari koperasi yang bertugas menjalankan kegiatan bisnis atau operasioanal, sedangkan tanggung jawab koperasi dalam ruang lingkup eksternal yaitu oleh koperasi sebagai badan hukum dan pemiliknya.

Tanggung jawab koperasi dalam ruang lingkup internal dan eksternal dapat dilihat salah satunya melalui pelaksanaan kreditdalam linkage program pola executing. Linkage program pola executing merupakan kerjasama yang saling membutuhkan dan menguntungkan antara bank dan koperasi dalam hal penyaluran kredit kepada Usaha Mikro Kecil dan Menengah (UMKM). Tanggung jawab internal koperasi dalam linkage program pola executing adalah terhadap para anggotanya yang meminjam dana melalui koperasi, sedangkan tanggung jawab eksternalnya adalah terhadap bank selaku pemberi pinjaman kredit.

Linkage program merupakan upaya Pemerintah dalam mengatasi permasalah yang dihadapi koperasi melalui perbankan. Pemberian pinjaman kredit melalui linkage program pola executing dalam pelaksanaannya dapat mengalami gagal bayar atau macet dan koperasi serta pemiliknya harus bertanggung jawab. Berdasarkan UU Perkoperasian tepatnya pada Pasal 17 Ayat (1), pemilik koperasi adalah anggota koperasi yang sekaligus berperan sebagai pengguna jasa koperasi.Namun dalam faktanya anggota koperasi tidak dapat dimintai pertanggungjawaban sebagai sebagai pemilik apabila terjadi masalah dalam hal ini kredit macet dan tidak mempunyai bukti kepemilikan yang jelas.

Koperasi sebagai sebuah badan usaha haruslah mempunyai pemilik dan bukti kepemilikan yang jelas, sehingga dapat memberikan kepastian hukum saat terjadi masalah dalam hal ini kredit macet atau gagal bayar hutang. Hal tersebut sejalan dengan salah satu bentuk badan usaha berbadan hukum lainnya yaitu Perseroan Terbatas (PT) dimana bukti kepemilikannya dibuktikan dengan saham sebagaimana diatur dalam Undang-Undang Nomor 40 Tahun 2007 Tentang Perseroan Terbatas (UU PT). Saham tersebut merupakan surat bukti kepemilikan atas sebuah badan usaha. Sehingga pemegang saham sebagai pemilik memiliki hak dan kewajiban serta bukti yang jelas guna menjalankan perannya.

Kepemilikan koperasi pada dasarnya sudah pernah diatur lebih jelas melalui Undang-Undang Nomor 17 Tahun 2012 tentang Perkoperasian.Dalam undang-undang tersebut disebutkan bahwa bukti anggota koperasi sebagai pemilik dan pengguna jasa 
koperasi adalah sertifikat modal koperasi.Namun undang-undang tersebut dibatalkan seluruhnya oleh Mahkamah Konstitusi melalui Putusan Nomor 28/PUU-XI /2013 dan untuk mengisi kekosongan hukum peraturan mengenai koperasi dikembalikan ke UU Perkoperasian.

Sertifikat modal koperasi sebagai bukti kepemilikan anggota koperasi dianggap sebagai norma yang tidak sesuai prinsip koperasi. Sertifikat modal koperasi dianggap sama seperti halnya saham dalam PT, sehingga ruh koperasi sebagai badan usaha berbadan hukum yang berlandaskan asas kekeluargaan menjadi hilang dan berubah menjadi berjiwa korporasi. Pemahaman tradisional yang menganggap sertifikat modal koperasi sama dengan saham menganggap sertifikat tersebut sebagai sebuat bentuk liberalisasi.

Sertifikat modal koperasi sesungguhnya tidaklah sama dengan saham pada badan usaha berbadan hukum PT, karena tidak berpengaruh pada hak suara dimana hak suara anggota adalah tetap, satu orang anggota satu suara. Sebanyak apapun kepemilikan sertifikat modal koperasi oleh anggota koperasi, tidak menambah hak suara anggota dalam rapat anggota sebagai kekuasaan tertinggi koperasi dan pemilik sertifikat modal koperasi hanyalah anggota koperasi tersebut saja, serta pemindahannya hanya dapat dilakukan kepada anggota lain ataupun kepada koperasinya.

Pembatalan Undang-Undang Nomor 17 Tahun 2012 tentang Perkoperasian dan dikembalikannya kepada UU Perkoperasian menyebabkan ketidakjelasan bukti kepemilikan koperasi.Bukti kepemilikan yang tidak jelas oleh anggota koperasi menyebabkan ketidakjelasan siapa pemilik koperasi sebenarnya. Pengurus koperasi sebagai pelaksana bisnis atau operasional koperasi juga tidak dapat dikatakan sebagai pemilik koperasi dikarenakan hanya bertugas sebatas wewenangnya. Tidak jelasnya kepemilikan tersebut menyebabkan ketidakpastian hukum saat koperasi mengalami masalah dalam hal ini kredit macet atau gagal bayar hutang.

Berdasarkan uraian di atas, maka Penulis tertarik untuk mengangkat beberapa permasalahan di antaranya: Pertama, bagaimana pengaturan kepemilikan koperasi berdasarkan hukum positif di Indonesia. Kedua, bagaimana konsep kepemilikan koperasi yang berdasarkan teori kepastian hukum. Ketiga, bagaimana tanggung jawab pemilik koperasi dalam terjadi kredit macet ditinjau dari teori kepastian hukum.

Penelitian ini bersifat deskriptif analitis dengan menggunakan pendekatan yuridis empiris.Penelitianyuridisempiris merupakan penelitian hukum mengenai implementasi atau pemberlakuan peraturan perundang-undangan pada setiap peristiwa hukum tertentu yang terjadi di masyarakat. Pendekatan yuridis empiris dilakukan dengan cara menelaah dan menginterpretasikan hal-hal yang bersifat teoritis menyangkut asas, konsepsi, doktrin dan norma hukum yang berkaitan dengan koperasi. Spesifikasi penelitian yang digunakan dalam penelitian ini adalah diskriptifanalisis, yaitu penelitian untuk memperoleh gambaran secara lengkap tentang keadaan hukum yang berlaku pada tempatdan waktu tertentu, mengenai gejala yuridis atau peristiwa hukum yang terjadi dalam masyarakat. Penenelitian yuridis normatif tersebut nantinya menitik beratkan kepada penelitian hukum kepustakaan dengan cara meneliti bahan pustaka atau data sekunder. Penelitian ini menggunakan bahan hukum primer, yaitu peraturan perundang-undangan yang berhubungan dengan koperasi dan bahan hukum sekunder yaitu buku, jurnal dan hasil-hasil penelitian yang berkaitan dengan masalahpenelitian. 


\section{PEMBAHASAN}

\section{Pengaturan Kepemilikan Koperasi Berdasarkan Hukum Positif di Indonesia}

Pembangunan ekonomi di Indonesia tidak dapat lepas dari dasar falsafah yang menjadi landasan kegiatan berbangsa dan bernegara, yaitu Pancasila dan UUD 1945. Dasar pembangunan ekonomi Indonesia tercantum dalam Pasal 33 UUD 1945 amandemen ke-IV yang menjadi landasan penyelenggaraan ekonomi nasional yang menyatakan bahwa perekonomian disusun dan dikembangkan sebagai usaha bersama seluruh rakyat berdasar asas keadilan, efesiensi, dan demokrasi untuk mewujudkan kemakmuran, kesejahteraaan, dan keadilan bagi seluruh rakyat Indonesia.

Kebijakan Pemerintah dalam pembangunan ekonomi sesuai dengan UUD 1945 harus diarahkan kepada terwujudnya demokrasi ekonomi, dimana masyarakat harus memegang peranan aktif dalam kegiatan pembangunan tersebut. ${ }^{7}$ Indonesia menganut asas demokrasi berdasarkan Pasal 33 UUD 1945 yang menyatakan bahwa perekonomian Indonesia berdasar atas asas demokrasi ekonomi. Dalam rangka mewujudkan asas demokrasi ekonomi, koperasi sebagai sarana untuk memajukan kesejahteraan anggota pada khususnya dan masyarakat pada umumnya, ikut membangun tatanan perekonomian nasional dalam rangka mewujudkan masyarakat yang maju, adil, dan makmur berlandaskan Pancasila dan UUD 1945. Koperasi memiliki peran yang sangat penting dalam perekonomian Indonesia.

Dalam batang tubuh UUD 1945 tersedia Bab khusus yakni tentang "Kesejahteraan Sosial" yang diterjemahkan melalui Pasal 33. ${ }^{8}$ Pasal 33 UUD 1945 merupakan pengakuan secara yuridis terhadap koperasi. ${ }^{9}$ Koperasi sebagai salah satu bentuk yang paling konkrit dari usaha bersama sesuai dengan Pasal 33 UUD 1945, perekonomian disusun sebagai usaha bersama berdasar atas kekeluargaan. Sejalan dengan pendapat Muhammad Hatta yang dimaksud dengan asas kekeluargaan itu adalah koperasi. Menurut Muhammad Hatta, koperasi adalah usaha bersama untuk memperbaiki nasib penghidupan ekonomi berdasarkan tolong menolong.

Kata koperasi berasal dari bahasa latincooperation yang berarti kerja sama atau bekerja sama. Di dalam koperasi terdapat orang-orang yang bekerja sama dalam menyelenggarakan berbagai kegiatan. Koperasi merupakan suatu badan usaha bersama dalam bidang ekonomi dengan tujuan membebaskan para anggotanya dari kesulitankesulitan ekonomi.Koperasi pada intinya merupakan badan usaha yang beranggotakan orang-orang atau badan hukum koperasi dengan melandaskan kegiatannya berdasarkan prinsip koperasi sekaligus sebagai gerakan ekonomi rakyat yang berdasarkan asas kekeluargaan dan bertujuan untuk menyejahterakan anggotanya. ${ }^{10}$

Koperasi merupakan soko guru perekonomian Indonesia yang mana makna dari istilah koperasi sebagai soko guru perekonomian tersebut dapat diartikan bahwa koperasi dalam fungsinya di perekonomian Indonesia sebagai pilar, penyangga utama,

${ }^{7}$ Teguh Tresna Puja Asmara dan Tarsisius Murwadji, "The Role of Academics in Corporate Social Responsibility to Increase Business Capacity ofMicro Small and Medium Enterprises", Jurnal Hukum POSITUM, Vol. 4, No. 1, 2019, hlm. 2 .

8 Agus Riwantodan Seno Wibowo Gumbira, "Politik Hukum Penguatan Fungsi Negara Untuk Kesejahteraan Rakyat (Studi Tentang Konsep Dan Praktik Negara Kesejahteraan Menurut UUD 1945)", Jurnal Hukum dan Peradilan, Vol. 6, No. 3, 2017, hlm. 338.

${ }^{9}$ Mochamad Adib Zain, "Politik Hukum Koperasi di Indonesia (Tinjauan Yuridis Historis Pengaturan Perkoperasian di Indonesia)", Jurnal Penelitian Hukum, Vol. 2, Nomor 3, 2015, hlm. 161.

${ }^{10}$ G. Karta Sapoetra, 2003, Koperasi Indonesia, Rineka Cipta, Jakarta, hlm. 2. 
atau tulang punggung. Koperasi diperankan dan difungsikan sebagai pilar utama dalam sistem perekonomian nasional. Keberadaannya pun diharapkan dapat banyak berperan aktif dalam mewujudkan kesejahteraan dan kemakmuran rakyat. ${ }^{11}$

Ciri utama koperasi adalah kerjasama anggota dengan tujuan untuk mencapai kesejahteraan hidup bersama. Hal ini dapat dilihat dari koperasi yang "dari, oleh dan untuk anggota". ${ }^{12}$ Koperasi dapat menjangkau seluruh lapisan masyarakat lebih luas dibanding lembaga keuangan lainnya termasuk perbankan. Kemampuan koperasi untuk menjangkau seluruh lapisan menengah ke bawah dapat dimanfatkan untuk berkerjasama dengan lembaga-lembaga keuangan lainnya, termasuk bank. Kerjasama yang dimaksud adalah kerjasama menyalurkan dana dari lembaga keuangan tersebut kepada anggota koperasi.

Fungsi koperasi yang utama adalah sebagai lembaga intermediasi keuangan, yaitu menghimpun dana dari para anggota dan menyalurkannya kepada anggota masyarakat serta masyarakat sekitarnya. Dari fungsi ini, koperasi mempunyai kelemahan yaitu dananya terbatas karena berasal dari iuran anggota, sedangkan setiap anggota membutuhkan dana untuk menjalankan usahanya. Dalam hal modal koperasi hanya berasal dari iuran anggota, maka koperasi ini kekurangan modal untuk menjalankan atau mengembangkan kegiatan usahanya. Sebagai solusinya dibutuhkan 'suntikan dana' dari lembaga keuangan lain dengan ketentuan lembaga keuangan tersebut tidak akan intervensi berlebihan atau menguasai kebijakan koperasi.

Tata kelola koperasi merupakan suatu sistem tata kelola demokratis dan mandiri untuk mengatur entitas koperasi berdasarkan prinsip-prinsip, nilai-nilai, dan filosofis koperasi melalui struktur organisasi yang efektif dan perangkat organisasi yang profesional. ${ }^{13}$ Peran koperasi sangat dirasakannya manfaatnya oleh anggota dikarenakan koperasi dapat menjadi sekolah untuk mendidik para anggotanya agar dapat menjalankan dan mengemudikan sendiri usaha-usahanya. ${ }^{14}$

Fungsi koperasi tidak dapat dipisahkan dari situasi dan kondisi dari latar belakang budaya Indonesia, sejarah dan cita-cita bangsa Indonesia. Fungsi koperasi dalam perekonomian di Indonesia di antaranya adalah: Koperasi berfungsi sebagai alat perjuangan rakyat Indonesia di bidang ekonomi untuk meningkatkan taraf hidup dan kedudukan ekonminya serta melaksanakan pasal 33 UUD 1945, koperasi berfungsi sebagai alat perjuangan rakyat untuk mewujudkan demokrasi ekonomi sebagai landasan masyarakat yang berkeadilan social, koperasi berfungsi sebagai gerakan masyarakat untuk mensukseskan pembangunan nasional Indonesia serta menjamin terwujudnya hari esok yang sejahtera dan bahagia, koperasi berfungsi sebagai sokoguru ekonomi nasional Indonesia yang menjamin kemajuan serta kemakmuran bersama rakyat Indonesia dan koperasi harus berfungsi sebagai alat pemersatu rakyat Indonesia yang miskin dan lemah ekonminya untuk mewujudkan masyarakat Indonesia yang adil dan makmur berdasarkan Pancasila dan UUD $1945 .{ }^{15}$

\footnotetext{
${ }^{11}$ Bambang Daru Nugroho, Melienda Permatasari, Nanda Arianti, dan Achmad Hagi Robby, "Bank Khusus Untuk Koperasi Dalam Menghadapi MEA", Acta Diurnal, Vol. 1, No. 1, 2017, hlm. 36.

${ }^{12}$ Agus Bambang Nugraha, "Politik Hukum Terhadap Koperasi Indonesia", Jurnal Cakrawala, Vol. 5, No. 2, 2016, hlm. 277.

${ }^{13}$ Siti Nurfitriani dan Nurul Husnah, "Analisis Tata Kelola dan Kinerja Koperasi Peternak Sapi di Jawa Barat", Jurnal Pengkajian Koperasi dan UKM, Vol. 8 No. 1, 2013, hlm. 22.

${ }^{14}$ Sagimun MD, 1988, Koperasi Indonesia, Haji Masagung, Jakarta, hlm.5-6.

${ }^{15}$ Ibid.
} 
Sedangkan berdasarkan Pasal 4 UU Perkoperasiandijelaskan lebih lanjut secara rinci mengenai fungsi dan peran koperasi yaitu:

a. membangun dan mengembangkan potesi dan kemampuan ekonomi anggota pada khususnya dan pada masyarakat pada umumnya untuk meningkatkan kesejahteraan ekonomi dan sosialnya;

b. berperan serta secara aktif dalam upaya mempertinggi kualitas kehidupan manusia dan masyarakat;

c. memperkokoh perekonomian rakyat sebagai dasar kekuatan dan ketahanan perkonomian nasional dengan koperasi sebagai sokogurunya;

d. berusaha untuk mewujudkan dan mengembangkan perkonomian nasional yang merupakan usaha bersama berdasar atas asas kekeluargaan dan demokrasi ekonomi. Tujuan koperasi adalah untuk meningkatkan taraf hidup dan kesejahteraan anggotaanggotanya.Tujuan koperasi di Indonesia yang lebih jauh dan lebih luhur adalah mencapai serta mewujudkan masyarakat Indonesia yang adil dan makmur berdasarkan Pancasila dan UUD 1945.Tujuan koperasi tersebut juga diatur dalam Pasal UU Perkoperasianyang menyatakan bahwa koperasi bertujuan memajukan kesejahteraan anggota pada khususnya dan masyarakat pada umumnya serta ikut membangun tatanan perekonomian Nasional dalam rangka mewujudkan masyarakat yang maju ,adil ,dan makmur berlandaskan Pancasila dan UUD1945."

Pemilik koperasi berdasarkan UU Perkoperasian tepatnya pada Pasal 17 Ayat (1) adalah anggota koperasi yang sekaligus berperan sebagai pengguna jasa koperasi. Namun dalam faktanya anggota koperasi tidak dapat dimintai pertanggungjawaban sebagai pemilik.Selain itu anggota koperasi tidak mempunyai bukti kepemilikan yang jelas terhadap koperasi tersebut.Pemilik dalam arti luas dapat diartikan sebagai orang perorangan atau badan hukum yang mempunyai hak, kewajiban, dan bukti kepemilikan terhadap suatu hal tertentu.

\section{Konsep Kepemilikan Koperasi Yang Berdasarkan Teori Kepastian Hukum}

UUD 1945 menyatakan dalam Pasal 1 Ayat (3) bahwa Indonesia adalah Negara hukum.Ketentuan pasal tersebut merupakan landasan konstitusional bahwa Indonesia adalah negara yang berdasarkan atas hukum.Hukum ditempatkan sebagai satu-satunya aturan main dalam kehidupan bermasyarakat, berbangsa dan bernegara.Sebagai sebuah Negara hukum, Indonesia wajib menjunjung tinggi nilai-nilai supremasi hukum sebagai landasan konstitusinya.Konsep negara hukum tersebut berakar dari paham kedaulatan hukum yang pada hakikatnya berprinsip bahwa kekuasaan tertinggi di dalam suatu negara adalah berdasarkan atas hukum.Negara hukum merupakan substansi dasar dari kontrak sosial setiap negara hukum. ${ }^{16}$

Negara hukum dalam perkembangannya senantiasa dipautkan dengan konstitusi negara, terutama dalam hal pengaturan dan penegasan tentang pembatasan kekuasaan negara untuk menjamin kemerdekaan dan hak-hak dasar warga negara dan perlindungannya.Esensi dari negara berkonstitusi adalah perlindungan terhadap hakhak asasi manusia.Atas dasar itu, keberadaan konstitusi dalam suatu negara merupakan kemutlakan (conditio sine quanon). Tidak ada satu negarapun di dunia ini yang tidak mempunyai konstitusi atau undang-undang dasar, Negara dan konstitusi merupakan dua lembaga yang tidak dapat dipisahkan satu dengan yang lain. Dengan demikian

\footnotetext{
${ }^{16}$ Jazim Hamidi dan Mustafa Lutfi,2009, Hukum Lembaga Kepresidenan Indonesia, Alumni, Malang, hlm. 9.
} 
dalam batas-batas minimal, negara hukum identik dengan negara yang berkonstitusional atau negara yang menjadikan konstitusi sebagai aturan main kehidupan kenegaraan, pemerintahan, dan kemasyarakatan. ${ }^{17}$

Kekuasaan tertinggi di dalam suatu negara hukum adalah hukum itu sendiri, oleh sebab itu seluruh alat perlengkapan negara apapun namanya termasuk warga negara harus tunduk dan patuh serta menjung tinggi hukum tanpa terkecuali. ${ }^{18} \mathrm{Hukum}$ sendiri diartikan sebagai seperangkat kaidah dan asas yang mengatur kehidupan manusia didalam masyarakat. Menurut Mochtar Kusumaatmadja, hukum tidak hanya sebatas peraturan saja, akan tetapi juga mencakup lembaga dan proses untuk mewujudkan hukum tersebut didalam kenyataan. ${ }^{19}$

Negara yang berdiri berdasarkan hukum memiliki empat (4) asas utama, yaitu: asas kepastian hukum (het rechtszekerheidsbeginsel), asas persamaan (het gelijkeheidsbeginsel), asas demokrasi (het democratischebeginsel), dan asas bahwa pemerintah dibentuk untuk melakukan pelayanan terhadap masyarakat (het beginsal van de dienende overhead, governmet for the people). ${ }^{20}$

Indonesia sebagai negara hukum wajib mengimplementasikan asas kepastian hukum. Asas kepastian hukum merupakan asas dalam negara hukum yang mengutamakan landasan peraturan perundang-undangan, kepatutan, dan keadilan dalam setiap kebijakan Penyelenggara Negara.Secara spesifik, asas kepastian hukum dapat diartikan sebagai hukum normatif berdasarkan peraturan perundang-undangan yang berlaku. Asas kepastian hukum tidak menimbulkan keragu-raguan (multi-interpretasi) dan logis dalam arti menjadi sistem norma dengan norma yang lain sehingga tidak berbenturan atau menimbulkan konflik norma yang ditimbulkan dari ketidakpastian.

Hukum dibuat tidak dalam ruang yang hampa namun lahir dari ketentuan yang hidup dalam masyarakat (ibi societas ibi ius). ${ }^{21}$ Pasal 5 dan Pasal 6 Undang-Undang Nomor 12 Tahun 2011 tentang Pembentukan Peraturan Perundang-undangan (UU Pembentukan PeraturanPerundang-undangan) mengatur syarat-syarat asas hukum yang harus selalu ada dalam sebuah aturan hukum. Asas kepastian hukum yang terdapat dalam Pasal 6 Ayat (1) Huruf (i) UU Pembentukan Peraturan, menyebutkan bahwa materi muatan peraturan perundang-undangan harus mencerminkan asas ketertiban dan kepastian hukum. Maksud dari "asas ketertiban dan kepastian hukum" adalah bahwa setiap materi muatan Peraturan Perundang-undangan harus dapat mewujudkan ketertiban dalam masyarakat melalui jaminan kepastian hukum.Di samping harus taat asas, peraturan perundang-undangan yang dibuat dan diberlakukan terhadap bidang tertentu, tidak boleh bertentangan antara satu dengan yang lainnya yang sederajat atau menurut hierarki peraturan perundang-undangan yang ada.

Prinsip-prinsip negara hukum berkembang seiring dengan perkembangan masyarakat dan negara. Terdapat dua macam negara hukum, yaitu negara hukum formil atau negara hukum klasik dan negara hukum dalam arti materiil atau negara hukum yang

\footnotetext{
${ }^{17}$ Sri Soemantri Martosoewignjo, 1992,Bunga Rampai Hukum Tata Negara Indonesia, Bulan Bintang,Bandung, hlm. 3.

${ }^{18}$ Hestu Cipto Handoyo, 2009,Hukum Tata Negara Indonesia "Menuju Konsolidasi Sistem Demokrasi”, Universitas Atma Jaya, Jakarta, hlm. 17.

${ }^{19}$ Mochtar Kusumaatmadja, 1976,Masyarakat dan Pembinaan Hukum Nasional, Bina Cipta, Bandung, hlm. 15.

${ }^{20}$ Edi Hudiata,"Rekonstruksi Hukum Penyelesaian Sengketa Pasar Modal Syariah: Penguatan Aspek Regulasi Untuk Memberikan Kepastian Hukum", Jurnal Hukum dan Peradilan, Vol. 6, No. 2, 2017, hlm. 302.

${ }^{21}$ Satjipto Rahardjo, 2004, Hukum Progresif (Penjelajahan Suatu Gagasan), Majalah Hukum Newsletter Nomor 59 Bulan Desember 2004, Yayasan Pusat Pengkajian Hukum,Jakarta, hlm. 1.
} 
bersifat modern. ${ }^{22}$ Perbedaan kedua model negara hukum tersebut terletak pada tugas negara. Dalam artian formil tugas Negara adalah melaksanakan peraturan perundangundangan untuk melaksanakan ketertiban atau lebih dikenal sebagai Negara penjaga malam (nachtwacker staats).Sementara dalam artian materiil tugas negara tidak hanya sebatas menjaga ketertiban saja, melainkan juga kehadiran negara adalah untuk mecapai kesejahteraan rakyat untuk mecapai keadilan (welfare state).

Fungsi negara dalam arti materiil menjadikan yang utama bagi sebuah negara adalah bertindak sebagai pelayan bagi masyarakat (public service), dalam rangka meningkatkan kesejahteraan masyarakat tersebut. ${ }^{23}$ Fungsi negara dalam mewujudkan sebuah keadilan sosial di masyarakat tersebut, merupakan konsep yang disebut dengan konsep negara hukum kesejahteraan.

Konsep negara hukum kesejahteraan menjadi landasan kedudukan dan fungsi pemerintah (bestuurfunctie) dalam negara-negara modern.Negara kesejahteraan merupakan antitesis dari konsep negara hukum formal, yang didasari oleh pemikiran untuk melakukan pengawasan yang ketat terhadap penyelenggara kekuasaan negara. ${ }^{24}$ Suatu negara dapat digolongkan sebagai negara kesejahteraan apabila mempunyai empat pilar utamanya, yaitu: (i) social citizenship; (ii) full democracy; (iii) modern industrial relation systems; serta (iv) rights to education and the expansion of modern mass education systems. ${ }^{25}$

Indonesia merupakan negara yang menganut konsep negara kesejahteraan (welfare state).Teori mengenai Indonesia merupakan negara kesejahteraan bukanlah merupakan pembacaan yang ahistoris atau retrospektif karena sudah sejak masa-masa persiapan kemerdekaan, para pendiri bangsa mencita-citakan terbentuknya negara kesejahteraan di Indonesia.Cita-cita itu kemudian diterjemahkan ke dalam sila ke-lima Pancasila "Keadilan sosial bagi seluruh Indonesia" dan beberapa pasal dalam konstitusi atau UUD 1945, di antaranya Pasal 27 (2), 31, 33, dan 34. ${ }^{26}$

Dasar pembangunan ekonomi di Indonesia diterjemahkan dalam Pasal 33 UUD 1945 Amandemen IV yang menjadi landasan penyelenggaraan ekonomi nasional yang menyatakan, bahwa perekonomian disusun dan dikembangkan sebagai usaha bersama seluruh rakyat secara berkelanjutan berdasar asas keadilan, efisiensi, dan demokrasi ekonomi untuk mewujudkan kemakmuran, kesejahteraan, dan keadilan sosial bagi seluruh rakyat. ${ }^{27}$

Pasal 33 UUD 1945 merupakan pesan moral dan pesan budaya dalam konstitusi Republik Indonesia di bidang kehidupan ekonomi.Pasal ini bukan sekedar memberikan petunjuk tentang susunan perekonomian dan wewenang negara mengatur kegiatan perekonomian dan wewenang negara mengatur kegiatan perekonomian, yang mencerminkan cita-cita, yaitu suatu keyakinan yang dipegang teguh serta diperjuangkan secara konsisten oleh para pimpinan pemerintah. ${ }^{28}$ Pesan konstitusianal tersebut tampak jelas, bahwa yang dituju adalah suatu sistem ekonomi tertentu, yang bukan ekonomi

${ }^{22}$ Elien Utrecht, 1962, Pengantar Hukum Administrasi Negara Indonesia, Ichtiar,Jakarta, hlm. 9.

${ }^{23}$ Hestu Cipto Handoyo, Op. Cit., hlm. 20.

${ }^{24}$ W. Riawan Tjandra, 2014, Hukum Sarana Pemerintahan, Cahaya Atma Pustaka, Jakarta, hlm. 1.

${ }^{25}$ Darmawan Triwibowo dan Sugeng Bahagijo, Op. Cit. hlm. 9.

${ }^{26}$ Yudi Latif, Op.Cit., hlm. 584.

${ }^{27}$ Etty Mulyati, 2016, Kredit Perbankan Aspek Hukum Dan Pengembangan Usaha Mikro Kecil Dalam Pembangunan Perekonomian Indonesia, Refika Aditama, Bandung, hlm. 1.

${ }^{28}$ Bagir Manan, 1995,Pertumbuhan dan Perkembangan Konstitusi Suatu Negara, Mandar Maju, Bandung, hlm. 45. 
kapitalistik (berdasar paham individualisme), namun suatu sistem ekonomi berdasar kebersamaan dan berdasar atas asas kekeluargaan. ${ }^{29}$

Usaha bersama berdasar atas asas kekeluargaan contoh idealnya adalah koperasi, sebagaimana telah diatur dalam UU Perkoperasian. ${ }^{30}$ Koperasi juga sering disebut sebagai soko guru perekonomian Indonesia. ${ }^{31}$ Berdasarkan Pasal 1 Ayat (1) UU Perkoperasian dijelaskan bahwa koperasi merupakan badan usaha yang beranggotakan orang-seorang atau badan hukum koperasi dengan melandaskan kegiatannya berdasarkan prinsip koperasi sekaligus sebagai gerakan ekonomi rakyat yang berdasar atas asas kekeluargaan. Koperasi merupakan suatu badan usaha yang diakui dan dianggap sebagai bentuk usaha yang cocok untuk negara Indonesia. ${ }^{32}$

Fungsi utama koperasi adalah sebagai lembaga intermediasi keuangan, yaitu menghimpun dana dari para anggota dan menyalurkannya kepada anggota atau non anggota. Sebagai lembaga intermediasi, koperasi mempunyai kelemahan yaitu terkait keterbatasan dana yang hanya berasal dari iuran anggota saja, sedangkan koperasi membutuhkan dana yang cukup besar untuk menjalankan usahanya. Masalah kekurangan dana koperasi tersebut salah satunya dapat diatasi dengan kredit melaluilinkage program perbankan.

Linkage program merupakan kerjasama yang saling menguntungkan antara bank umum dan lembaga keuangan mikro, bank perkreditan rakyat, koperasi atau lembaga pembiayaan lainnya. Dalam Peraturan Menteri Negara Koperasi dan Usaha Kecil dan Menengah Republik Indonesia Nomor : 03/Per/M.KUKM/III/2009 Tentang Pedoman Umum Linkage Program antara Bank Umum dengan Koperasi (Permen Linkage Program) diatur tentang model-model linkage program antara bank umum dengan koperasi yang terbagi ke dalam tiga model atau bentuk yaitu pola executing, pola channeling, dan pola joint financing.

Linkage program pola executing merupakan pinjaman yang diberikan oleh bank umum kepada koperasi dalam rangka pinjaman atau pembiayaan untuk disalurkan kepada anggota koperasi.Teknisnya, pencatatan pinjaman atau pembiayaan tersebut di bank umum di catat sebagai pinjaman kepada koperasi, sedangkan pencatatan di koperasi sebagai pinjaman kepada anggota koperasi.

Koperasi dipilih sebagai sarana pemberian kredit bank kepada UMKM karena koperasi merupakan badan usaha yang berangotakan orang seorang atau badan hukum dengan melandaskan kegiatanya berdasarkan prinsip koperasi sekaligus sebagai gerakan ekonomi rakyat yang beradasar atas asas kekeluargaan sebagaimana diatur dalam UU Perkoperasian.Melalui linkage program ini maka bank umum dapat meminimalkan risiko yang timbul karena bank kurang paham dalam mengindentifikasi pelaku UMKM yang potensial.

Pemberian pinjaman kredit melalui linkage program pola executing tersebut berpotensi macet dan gagal bayar, sehingga koperasi harus bertanggungjawab danapabila harta koperasi tidak mencukupi maka pemilik koperasi juga dapat dimintai pertanggungjawaban. Dalam koperasi terdapat ketidakjelasan siapa pemilik dari koperasi, bukti apa yang dimilikinya, apa saja haknya, dan sejauh mana tanggung

\footnotetext{
${ }^{29}$ Herman Soewardi, 1989,Koperasi (Suatu Kumpulan Makalah), Ikopin,Bandung, hlm. 413.

${ }^{30}$ Mohammad Hatta, 1981, Pengertian Pancasila, Cetakan ke-3, PT. Inti Idayu Press, Jakarta, hlm. 36.

${ }^{31}$ Elli Ruslina, 2013, Dasar Perekonomian Indonesia Dalam Penyimpanan Mandat Konstitusi UUD Negara Tahun 1945, Total Media, Jakarta, hlm. 368.

${ }^{32}$ Myra Rosana, "Konsep Hukum Koperasi Modern Bagl Koperasi Sebagai Organisasi Perusahaan Berstatus Badan Hukum Sempurna”, Jurnal Hukum dan Pembangunan, Edisi Khusus Dies Natalis 85 Tahun FHUI, 2009, hlm. 202.
} 
jawabnya. Anggota yang disebut sebagai pemilik memiliki karakteristik yang berbeda dengan konsep pemilik berdasarkan teori kepastian hukum.

Kepemilikan terhadap badan usaha atau badan hukum mengakibatkan adanya pemisahan harta kekayaan dari pemilik untuk kepentingan operasional badan usaha atau badan hukum. Pemisahan harta kekayaan dari pemilik akan berubah menjadi hak-hak dan kewajiban terhadap badan usaha atau badan hukum tersebut. Pemilik juga memiliki kewenangan guna menjalankan badan usaha yang didelegasikan kepada pengurus atau organ perusahaan.

Struktur kepemilikan dalam suatu badan usaha atau badan hukum memiliki konsekuensi yang proporsional terhadap hak dan tanggung jawab pemilik sesuai dengan porsi kepemilikannya.Dalam badan usaha atau badan hukum di era modern ini, kepemilikan terhadap suatu badan usaha atau badan hukum dapat dilakukan dengan menggunakan tekhnologi yang muktahir. Pengggunaan tekhnologi dalam proses kepemilikan suatu badan usaha atau badan hukum dapat dilakukan oleh investor dengan mudah, cepat dan aman. Salah satu wujud dari penggunaan tekhnologi dalam proses kepemilikan badan usaha atau badan hukum adalah pembelian saham secara online.

Pemilik adalah orang yang memisahkan hartanya sebagai modal badan usaha atau badan hukum dan berubah menjadi hak serta tanggung jawab terhadap badan usaha atau badan hukum tersebut.Kepemilikan terhadap badan usaha atau badan hukum oleh pemilik, selain mempengaruhi nilai dan pengelolaan terhadap badan usaha atau badan hukum juga berpengaruh terhadap pertanggungjawaban di dalam badan usaha tersebut. Pemilik menurut Black's Law Dictionary, adalah istilah yang diterapkan atau disematkan kepada seseorang atau badan yang memiliki sesuatu aset. Klaim atau kepemilikan terhadap suatu aset dalam hal ini badan usaha atau badan hukum tersebut dapat dibuktikan dan diakui secara sah. Menurut International Financial Reporting Standard, pemilik adalah pemegang kepentingan ekuitas dalam entitas badan usaha atau badan hukum. Kepentingan ekuitas (equity interest) diartikan secara luas, mencakup kepentingan kepemilikan dalam entitas yang dimiliki dan kepentingan pemilik, serta tanggung jawab pemilik dalam badan usaha.

Pemilik dalam koperasi berdasarkan UU Perkoperasian adalah anggota yang sekaligus berperan sebagai pengguna jasa koperasi. Keanggotaan koperasi yang dalam hal ini didefinisikan sebagai pemilik hanya dibuktikan dengan catatan dalam buku daftar anggota. Pemilik badan usaha atau badan hukum pada dasarnya berbeda dengan karakteristik anggota.Pemilik dalam badan usaha dan badan hukum harus memisahkan harta kekayaannya untuk keperluan operasional badan usaha atau badan hukum. Pemilik juga mempunyai tanggung jawab saat badan usaha atau badan hukum tersebut mempunyai masalah.Selain memiliki hak atas keuntungan yang dihasilkan oleh badan usaha atau badan hukum, pemilik juga dapat mempunyai hak untuk menjadi pengurus atau yang berperan menjalankan operasional perusahaan.Guna menciptakan kepastian hukum, pemilik mempunyai bukti kepemilikan yang dapat dipertanggungjawabakan. Anggota dalam suatu badan usaha atau badan hukum harus dimaknai berbeda dengan pemilik. Hal ini tiada lain dikarenakan anggota hanya memiliki hak sebagai penerima jasa di dalam badan usaha atau badan hukum.

Guna memberikan kepastian hukum di dalam kepemilikan koperasi maka Penulis mengusulkan konsep kepemilikan koperasi yang berdasarkan asas kepastian hukum dengan tetap memperhatikan Undang-Undang Nomor 17 Tahun 2012 tentang 
Perkoperasian yang telah dibatalkan oleh Mahkamah Konstitusi. Konsep kepemilikan yang Penulis usulkan adalah dengan membedakan antara anggota dan pemilik di dalam koperasi.Dimana nantinya tidak semua anggota menjadi pemilik dan semua pemilik sudah tentu merupakan anggota.Anggota yang ingin menjadi pemilik harus memenuhi persyaratan-persyaratan untuk menjadi pemilik di koperasi diantaranya memberikan sejumlah harta atau aset guna kekayaan koperasi dan tidak serta merta harta atau aset tersebut dapat ditarik kapan saja oleh pemilik.Selain itu pemilik juga memiliki hak, kewajiban dan bukti kepemilikan yang berbeda dengan anggota koperasi.

Tanggung Jawab Pemilik Koperasi dalam Terjadi Kredit Macet Ditinjau dari Teori Kepastian Hukum

Tujuan koperasi utamanya adalah meningkatkan taraf hidup dan kesejahteraan anggota-anggotanya. Pada asasnya koperasi bukanlah suatu usaha yang mencari keuntungan semata-mata seperti halnya usaha-usaha seperti badan hukum lainnya yaitu firma dan perseroan. Koperasi berusaha memenuhi dan mencukupi kebutuhan seharihari anggotanya. Usaha koperasi biasanya disesuaikan dengan kebutuhan anggotanya. ${ }^{33}$

Dewasa ini, koperasi disamping membutuhkan modal untuk melaksanakan kegiatan usahanya, lebih membutuhkan pendidikan atau edukasi untuk mendapatkan pengarahan agar koperasi yang dibentuk dapat berjalan dengan sehat dan menghasilkan keuntungan yang dapat mensejahterakan anggotanya. Pendidikan terhadap koperasi ini dibutuhkan tidak hanya untuk mengarahkan koperasi agar maju tetapi juga masih minimnya pengetahuan dari pengurus maupun anggota tentang teknologi. Teknologi ini menjadi kebutuhan untuk koperasi saat ini apabila ingin diterima di masyarakat karena dapat mengikuti zaman yang lebih maju. ${ }^{34}$

Tujuan daripada pendidikan ini sendiri untuk membuat koperasi menjadi lebih mandiri kedepannya, seperti halnya saat ini koperasi dalam memenuhi kebutuhan modal usaha harus bekerja sama dengan pemilik modal, baik perorangan maupun lembaga keuangan. Namun, pada praktiknya banyak koperasi yang kesusahan dalam mendapatkan kredit modal usaha dari bank. Koperasi sendiri merupakan bentuk usaha yang unik hal itu dikarenakan kebanyakan anggota koperasi adalah pelaku usaha yang tidak berbadan usaha dan atau berbadan hukum. Sehingga, selain kebutuhan permodalan, koperasi juga membutuhkan pembinaan yang maksimal agar suatu saat anggota koperasi dapat mandiri.

Lembaga perbankan baik konvensional dengan berbagai prinsip dan pola perkreditannya masih profit oriented dan prinsip seperti itu belum dapat memenuhi kebutuhan Koperasi terutama dalam memperoleh kredit mengingat risiko yang dapat ditimbulkan dan juga masih lembaga perbankan masih banyak yang belum optimal melaksanakan linkage program. Permasalahan yang dihadapi Koperasi.

Berdasarkan hasil penelitian di beberapa Koperasi dan UMKM di Kelurahan Cipacing, Kecamatan Jatinangor, Kabupaten Sumedang, di Koperasi Peternak Sapi Bandung Utara dan di Koperasi Peternak Bandung Selatan, yang menjadi masalah yang dihadapi koperasi pada umumnya, yaitu : $:^{35}$

${ }^{33}$ Tarsisius Murwadji, 2018, "Kajian Hukum Penyehatan Koperasi Melalui Program Linkage Perbankan Menuju Pembentukan Bank Koperasi Menghadapi Masyarakat Ekonomi Asean Bidang Perbankan Tahun 2020", Laporan Penelitian Terapan Unggulan Perguruan Tinggi, Dikti, Jakarta, hlm. 102.

${ }^{34}$ Ibid., hlm. 103.

35 Tarsisius Murwadji, 2018, "Audit Mutu Hukum Pengaturan Dan Penerapan Pertanggungjawaban Sosial Bank Dalam Meningkatkan Kapasitas Bisnis Koperasi Di Provinsi Jawa Barat", Laporan Penelitian Academic Leadership Grant, Universitas Padjadjaran, Bandung, hlm. 112. 
1. Koperasi jarang peminatnya. Menurut pengurus Koperasi, bahwa koperasi jarang peminatnya dikarenakan ada pandangan masyarakat bahwa koperasi adalah lembaga yang identic dengan golongan masyarakat bawah, selain itu saat ini banyaknya koperasi yang melakukan kegiatan tidak sesuai dengan asas-asas koperasi. Oleh karena itu perlu adanya sosialisasi kepada masyarakat tentang koperasi. Dengan adanya sosialisasi diharapkan pengetahuan masyarakat tentang koperasi akan bertambah. Masyarakat dapat mengetahui bahwa sebenarnya koperasi merupakan ekonomi rakyat yang dapat mensejahterakan anggotanya. Sehingga mereka berminat untuk bergabung;

2. Kualitas sumber daya yang terbatas. Sumber daya manusia yang dimaksud adalah penguruskoperasi.Sepertiyangseringdijumpai, penguruskoperasibiasanyamerupakan tokoh masyarakat sehingga dapat dikatakan rangkap jabatan, kondisi seperti inilah yang menyebabkan ketidakfokusan terhadap pengelolaankoperasiitusendiri. Selainitu pengurus koperasi biasanya sudah lanjut usia sehingga kapasitasnya terbatas. Banyak anak muda sekarang lebih memilih bank daripada koperasi. Sehingga, perlu dilakukan pengarahan tentang koperasi kepada generasi muda melalui pendidikan agar mereka dapat berpartisipasi dalam koperasi;

3. Keterbatasan modal. Koperasi sendiri bertujuan mensejahterakan anggotanya. Untuk itu, koperasi juga membutuhkan modal dalam menjalankan kegiatan usaha, namun keterbatasan modal menjadi hal yang sangat mempengaruhi perkembangan koperasi. Saat ini, tidak banyak bank yang dapat memberikan kemudahan bagi koperasi dalam mengajukankredit.Saatini,bankyangadatidakbanyakyangbiasmemahamikebutuhan koperasi. Selanjutnya juga Pemerintah perlu memberikan perhatian kepada koperasi yang memang kesulitan dalam masalah permodalan. Dengan pemberian modalkoperasi dapat memperluas usahanya sehingga dapat bertahan dan dapat berkembang. Selain pemerintah, masyarakat merupakan pihak yang tak kalah pentingnya, dimana mereka yang memiliki dana lebih dapat menyimpan uang mereka dikoperasi yang nantinya dapat digunakan untuk modal koperasi;

4. Manajemen koperasi. Pelaksanaan koperasi tentunya memerlukan manajemen, baik daribentuk perencanaan, pengorganisasian, pengarahan, dan pengawasan. Karena hal ini sangat berfungsi dalam pengambilan keputusan tetapi tidak melupakan partisipasi dari anggota. A pabila semua kegiatan koperasi dapat dijalankan dengan baik dan setiap anggota mau mengambil bagian di dalam kegiatan koperasi serta perhatian pemerintah dapat memberikan motifasi yang baik, koperasi pasti dapat berjalan dengan lancar.

Dalam hal kekurangan modal koperasi dapat bekerjasama dengan lembaga keuangan dalam hal ini perbankan. Salah satu program guna mengembangkan koperasi tersebut yaitu linkage program perbankan. Linkage rrogram adalah program kerjasama antara bank umum termasuk bank umum peserta KUR (Kredit Usaha Rakyat) dengan Koperasi dalam rangka meningkatkan akses pembiayaan Usaha Mikrodan Kecil.Linkage program bertujuan untuk memperluas akses kredit kepada pelaku usaha mikro yang sulit dijangkau oleh perbankan.Linkage program juga bertujuan untuk mempercepat pencapaian business plan kredit Bank Umum kepada UMK serta mengatasi keterbatasan jaringan dan sumber daya manusia Bank Umum dalam menjangkau UMK secara langsung di daerah.

Model linkage program antara Bank umum dengan koperasi dapat dilakukan dalam bentuk salah satunya yaitu melalui pola executing. Linkage program pola executing merupakan pinjaman yang diberikan oleh bank umum kepada Koperasi dalam rangka 
pinjaman/pembiayaan untuk disalurkan kepada anggota koperasi. Pencatatan di Bank umum sebagai pinjaman kepada Koperasi, sedangkan pencatatan di koperasi sebagai pinjaman kepada anggota koperasi.

Koperasi dipilih sebagai sarana pemberian kredit bank kepada UMKM karena koperasi merupakan badan usaha yang berangotakan orang seorang atau badan hukum dengan melandaskan kegiatanya berdasarkan prinsip koperasi sekaligus sebagai gerakan ekonomi rakyat yang beradasar atas asas kekeluargaan sebagaimana diatur dalam UU Perkoperasian.Melalui linkage program ini maka bank umum dapat meminimalkan risiko yang timbul karena bank kurang paham dalam mengindentifikasi pelaku UMKM yang potensial.

Pemberian pinjaman kredit melalui linkage program pola executing tersebut berpotensi macet dan gagal bayar, sehingga koperasi harus bertanggungjawab dan apabila harta koperasi tidak mencukupi maka pemilik koperasi dapat dimintai pertanggungjawaban. Dalam koperasi terdapat ketidakjelasan siapa pemilik dari koperasi tersebut, bukti apa saja yang dimilikinya, apa saja haknya, dan sejauh mana tanggung jawabnya.

Berdasarkan UU Perkoperasian tepatnya pada Pasal 17 Ayat (1), pemilik koperasi adalah anggota koperasi yang sekaligus berperan sebagai pengguna jasa koperasi. Namun dalam faktanya anggota koperasi tidak dapat dimintai pertanggungjawaban sebagai pemilik.Selain itu anggota koperasi tidak memiliki bukti kepemilikan yang jelas terhadap koperasi.

Tanggung jawab merupakan suatu keseharusan bagi seseorang atau badan usaha untuk melaksanakan apa yang telah diwajibkan kepadanya.Menurut hukum tanggung jawab adalah suatu akibat atas konsekuensi kebebasan seseorang atau badan usaha atas perbuatannya. Pertanggungjawaban harus mempunyai dasar, yaitu hal yang menyebabkan timbulnya hak hukum bagi seorang untuk menuntut orang lain sekaligus berupa hal yang melahirkan kewajiban hukum orang lain untuk memberi pertanggungjawabannya.

Pertanggungjawaban koperasi dalam menjalankan usahanya terbagi ke dalam dua ruang lingkup, yaitu internal dan eksternal.Tanggung jawab koperasi dalam ruang lingkup internal yaitu oleh pengurus dari koperasi itu sendiri yang bertugas menjalankan kegiatan bisnis atau operasioanal, sedangkan tanggung jawab koperasi dalam ruang lingkup eksternal yaitu oleh koperasi sebagai badan hukum dan pemiliknya.

Pertanggungjawaban pengurus dapat terjadi apabila koperasi menderita kerugian. Maka dalam hal ini ada dua kategori kesalahan yang dapat terjadi atas pengelolaan pengurus.Pertama, apabila kerugian atas kesengajaan atau kelalaian pengurus sehingga menimbulkan kerugian koperasi, maka dalam hal demikian dapat digunakan doktrin ultra vires. Kedua, pengurus bertanggungjawab penuh secara pribadi apabila dalam menjalankan tugasnya menimbulkan kerugian bagi koperasi dan tindakan pengurus di luar Anggaran Dasar dan ketentuan lain yang berlaku di koperasi.

Berbeda dengan pengurus, tanggung jawab pemilik koperasi adalah pada saat koperasi mengalami masalah dalam hal ini kredit macet dan harta kekayaan koperasi tersebut tidak mencukupi untuk memenuhi kewajibannya.Tanggung jawab pemilik tersebut dapat sampai ke harta pribadinya.Namun di koperasi terdapat ketidakjelasan terkait pemilik koperasi sehingga menciptakan ketidakpastian hukum.Syarat kepemilikan ditinjau dari teori kepastian hukum terbagi ke dalam tiga bentuk yaitu bukti kepemilikan, hak-hak 
pemilik, dan tanggung jawab pemilik.Syarat kepemilikan tersebut mutlak harus ada dalam sebuah aturan hukum.

\section{SIMPULAN}

Koperasi merupakan badan usaha yang beranggotakan orang seorang atau badan hukum koperasi dengan melandaskan kegiatannya berdasarkan prinsip koperasi sekaligus sebagai gerakan ekonomi rakyat yang berdasarkan atas asas kekeluargaan. Pemilik koperasi berdasarkan Pasal 17 Ayat (1) UU Perkoperasian adalah anggota koperasi yang sekaligus berperan sebagai pengguna jasa koperasi. Namun dalam faktanya anggota koperasi tidak dapat dimintai pertanggungjawaban sebagai pemilik. Pemilik dalam arti luas dapat diartikan sebagai orang perorangan atau badan hukum yang mempunyai hak, kewajiban, dan bukti kepemilikan terhadap suatu hal tertentu.

Ketidakjelasan pemilik koperasi menciptakan ketidakpastian hukum terutama bagi pihak-pihak yang melakukan hubungan hukum dengan koperasi. Syarat kepemilikan ditinjau dari teori kepastian hukum terbagi ke dalam tiga bentuk yaitu bukti kepemilikan, hak-hak pemilik, dan tanggung jawab pemilik. Anggota koperasi yang disebut sebagai pemilik dalam UU Perkoperasian memiliki karakteristik yang berbeda dengan konsep pemilik berdasarkan teori kepastian hukum.

Tanggung jawab pemilik koperasi adalah dapat sampai dengan harta pribadinya. Namun pertanggungjawaban terhadap pemilik tersebut dapat dibebankan pada saat koperasi atau harta kekayaan koperasi tidak mencukupi untuk memenuhi kewajibannya. Diperlukan revisi terhadap UU Perkoperasian terutama yang mengatur kepemilikan sebagaimana terdapat dalam Pasal 17 Ayat (1), agar dapat mengatur secara jelas dan rinci mengenai hak-hak, tanggung jawab, dan bukti kepemilikan pemilik koperasi sehingga dapat menciptakan kepastian hukum.

\section{DAFTAR PUSTAKA}

\section{Buku}

Abdulkadir Muhammad, (2010), Hukum Perusahaan Indonesia, Cetakan Ke Empat Revisi, PT Citra Aditya Bakti, Bandung.

Bagir Manan, (1995),Pertumbuhan dan Perkembangan Konstitusi Suatu Negara, Mandar Maju, Bandung.

Darmawan Triwibowo dan Sugeng Bahagijo, (2006), Mimpi Negara Kesejahteraan, LP3ES, Jakarta.

Elien Utrecht, (1962), Pengantar Hukum Administrasi Negara Indonesia, Ichtiar,Jakarta.

Elli Ruslina, (2013), Dasar Perekonomian Indonesia Dalam Penyimpanan Mandat Konstitusi UUD Negara Tahun 1945, Total Media, Jakarta.

Etty Mulyati, (2016), Kredit Perbankan Aspek Hukum Dan Pengembangan Usaha Mikro Kecil Dalam Pembangunan Perekonomian Indonesia, Refika Aditama, Bandung.

G. Karta Sapoetra, (2003), Koperasi Indonesia,Rineka Cipta, Jakarta.

Herman Soewardi, (1989),Koperasi (Suatu Kumpulan Makalah), Ikopin,Bandung.

Hestu Cipto Handoyo, (2009),Hukum Tata Negara Indonesia "Menuju Konsolidasi SistemDemokrasi", Universitas Atma Jaya, Jakarta. 
Jazim Hamidi dan Mustafa Lutfi, (2009), Hukum Lembaga Kepresidenan Indonesia, Alumni, Malang.

Mochtar Kusumaatmadja, (1976),Masyarakat dan Pembinaan Hukum Nasional, Bina Cipta, Bandung.

Mohammad Hatta, (1981), Pengertian Pancasila, Cetakan ke-3, PT. Inti Idayu Press, Jakarta.

Sagimun MD, (1988), Koperasi Indonesia, Haji Masagung, Jakarta.

Satjipto Rahardjo, (2004), Hukum Progresif (Penjelajahan Suatu Gagasan), Majalah Hukum Newsletter Nomor 59 Bulan Desember 2004, Yayasan Pusat Pengkajian Hukum, Jakarta.

Sri Soemantri Martosoewignjo, (1992),Bunga Rampai Hukum Tata Negara Indonesia, Bulan Bintang,Bandung.

W. Riawan Tjandra, (2014), Hukum Sarana Pemerintahan, Cahaya Atma Pustaka, Jakarta.

Yudi Latif, (2011), Negara Paripurna: Historisitas, Rasionalitas, dan Aktualitas Pancasila, Gramedia Pustaka Utama, Jakarta.

\section{Jurnal}

Agus Bambang Nugraha, (2016) "Politik Hukum Terhadap Koperasi Indonesia", Jurnal Cakrawala, Vol. 5, No. 2, 271-298.

Agus Riwanto dan Seno Wibowo Gumbira, (2017) "Politik Hukum Penguatan Fungsi Negara Untuk Kesejahteraan Rakyat (Studi Tentang Konsep Dan Praktik Negara Kesejahteraan Menurut UUD 1945)", Jurnal Hukum dan Peradilan, Vol. 6, No. 3, 337-360.

Bambang Daru Nugroho, Melienda Permatasari, Nanda Arianti, dan Achmad Hagi Robby, (2017), "Bank Khusus Untuk Koperasi Dalam Menghadapi MEA", ACTA DIURNAL, Vol. 1, No. 1, 31-46.

Dian Cahyaningrum, (2017), "Bentuk Badan Hukum Koperasi Untuk Menjalankan Kegiatan Usaha Perbankan", Jurnal Negara Hukum, Vol. 8, No. 1, 1-30.

Edi Hudiata, (2017), "Rekonstruksi Hukum Penyelesaian Sengketa Pasar Modal Syariah: Penguatan Aspek Regulasi Untuk Memberikan Kepastian Hukum", Jurnal Hukum dan Peradilan, Vol. 6, No. 2, 297-316.

Mochamad Adib Zain,(2015), "Politik Hukum Koperasi di Indonesia (Tinjauan Yuridis Historis Pengaturan Perkoperasian di Indonesia)", Jurnal Penelitian Hukum, Vol. 2, Nomor 3, 160-177.

Myra Rosana, (2009), "Konsep Hukum Koperasi Modern Bagl Koperasi Sebagai Organisasi Perusahaan Berstatus Badan Hukum Sempurna', Jurnal Hukum dan Pembangunan, Edisi Khusus Dies Natalis 85 Tahun FHUI, 201-216.

Rustam Effendi, Boy Syamsul Bakhri, dan Zul Ihsan Mu'arrif, (2018), "Konsep Koperasi Bung Hatta Dalam Perspektif Ekonomi Syariah", Jurnal Al-Hikmah, Vol. 15, No. 1, 111-135.

Siti Nurfitriani dan Nurul Husnah, (2013), "Analisis Tata Kelola dan Kinerja Koperasi 
Peternak Sapi di Jawa Barat", Jurnal Pengkajian Koperasi dan UKM, Vol. 8 No. $1,41-57$.

Tarsisius Murwadji dan Achmad Hagi Robby, (2017), "Edukasi dan Penyehatan Koperasi Melalui Linkage Program Perbankan", Padjadjaran Jurnal Ilmu Hukum, Vol. 4, No. 3, 454-472.

Teguh Tresna Puja Asmara dan Tarsisius Murwadji, (2019), "The Role of Academics in Corporate Social Responsibility to Increase Business Capacity ofMicro Small and Medium Enterprises", Jurnal Hukum POSITUM, Vol. 4, No. 1, 1-13.

\section{Peraturan Perundang-undangan}

Undang-Undang Dasar Negara Republik Indonesia Tahun 1945.

Undang-Undang Nomor 25 Tahun 1992 tentang Perkoperasian.

Undang-Undang Nomor 10 Tahun 1998 Tentang Perubahan atas Undang-Undang Nomor 7 Tahun 1992 Tentang Perbankan.

Undang-Undang Nomor 20 Tahun 2008 Tentang Usaha Mikro Kecil dan Menengah.

Undang-Undang Nomor 40 Tahun 2007 Tentang Perseroan Terbatas.

Peraturan Menteri Negara Koperasi dan Usaha Kecil dan Menengah Republik Indonesia Nomor : 03/Per/M.KUKM/III/2009 Tentang Pedoman Umum Linkage Program antara Bank Umum dengan Koperasi.

\section{Sumber Lain}

Putusan Mahkamah Konstitusi Nomor: 28/PUU-XI /2013.

Tarsisius Murwadji, (2018), "Kajian Hukum Penyehatan Koperasi Melalui Program Linkage Perbankan Menuju Pembentukan Bank Koperasi Menghadapi Masyarakat Ekonomi Asean Bidang Perbankan Tahun 2020", Laporan Penelitian Terapan Unggulan Perguruan Tinggi, Dikti, Jakarta.

, (2018), "Audit Mutu Hukum Pengaturan Dan Penerapan Pertanggungjawaban Sosial Bank Dalam Meningkatkan Kapasitas Bisnis Koperasi Di Provinsi Jawa Barat", Laporan Penelitian Academic Leadership Grant, Universitas Padjadjaran, Bandung. 